\title{
SPOTKANIE Z CHRYSTUSEM JAKO PODSTAWA DUCHOWOŚCl OSÓB KONSEKROWANYCH WEDŁUG NAUCZANIA PAPIEŻA FRANCISZKA
}

DOI: http://dx.doi.org/10.12775/TiCz.2015.006

Dwudziestego dziewiątego listopada 2014 r. zainaugurowany został w Kościele nowy rok liturgiczny poświęcony życiu konsekrowanemu. Kongregacja Instytutów życia konsekrowanego i Stowarzyszeń życia apostolskiego z tej okazji wystosowała List okólny do osób konsekrowanych z nauczania papieża Franciszka pt. Radujcie się. Celem tego dokumentu jest zaproszenie do wspólnej refleksji i dostrzeżenie elementów wspólnych między orędziem Ewangelii a treścią życia osób konsekrowanych i ich świadectwem w świecie współczesnym ${ }^{1}$.

* Dr hab. Adam Józef Sobczyk - kapłan ze Zgromadzenia Misjonarzy Świętej Rodziny. Od 2009 roku członek korespondent Polskiego Stowarzyszenia Teologów Duchowości. Wykładowca teologii duchowości, kierownictwa duchowego i poradnictwa rodzin; rekolekcjonista. Zainteresowania naukowe obejmują głównie zagadnienia historii i teologii duchowości ze szczególnym uwzględnieniem duchowości zakonnej oraz duchowości małżeńskiej i rodzinnej.

1 Por. Kongregacja Instytutów życia konsekrowanego i stowarzyszeń życia apostolskiego. List okólny do osób konsekrowanych z nauczania papieża Franciszka, Radujcie się, Warszawa 2014, s. 10. 
Dokument ten, zachęcając do refleksji, podaje jednocześnie materiał źródłowy, którym jest nauczanie Papieża Franciszka. Powyższe przesłanki pozwalają na przypuszczenie, że analiza tego dokumentu może być bardzo interesująca i przydatna, gdyż przedstawi wykładnię nauczania Papieża Franciszka na temat życia zakonnego. Tym bardziej że Ojciec święty jest zakonnikiem i doskonale zna warunki życia oraz problemy osób konsekrowanych.

Od samego początku lektury Listu widać, że Papieskie nauczanie zostało przedstawione w atmosferze radości, w której powinni żyć i którą powinni rozwijać w sobie i wokół siebie zakonnicy i zakonnice. Ojciec święty twierdzi, że radość ta jest wynikiem spotkania z Jezusem. W swej adhortacji Ewangelii gaudium pisze: „radość ewangelii napełnia serce oraz całe życie tych, którzy spotykają się z Jezusem. Ci, którzy pozwalają, żeby ich zbawił, zostają wyzwoleni od grzechu, od smutku, od wewnętrznej pustki, od izolacji. Z Jezusem Chrystusem rodzi się zawsze i odradza radość”2.

Według Papieża spotkanie z Chrystusem daje radość i staje się świadectwem. Spotkanie $\mathrm{z}$ Jezusem rozpala $\mathrm{w}$ osobie konsekrowanej to pierwotne piękno, w którym odbija się obraz Stwórcy. Doświadczenie tej relacji wymaga, zdaniem papieża, przylgnięcia całym sercem do Pana. Ojciec święty zauważa, że w odróżnieniu od osób świeckich, zakonnicy idą za Jezusem w sposób profetyczny. To jest jednocześnie ich zadanie wobec świata ${ }^{3}$.

Jako wzór takiego profetyzmu osób konsekrowanych podaje papież Świętego Franciszka, który uczynił z Ewangelii formę życia. Adresatem zaś tego głoszenia są wszyscy ludzie na świecie bez wyjątku ${ }^{4}$.

\section{RADOŚĆ ZE SPOTKANIA Z BOGIEM W BIBLIl}

Omawianie tego zagadnienia Papież Franciszek rozpoczyna od wyjaśnienia etymologii słowa radość. Podkreśla jego związek z kultem religijnym i świętami mającymi na celu ukazanie obecności Boga w historii Na-

${ }^{2}$ Franciszek, Adhortacja apostolska Evangelii gaudium (dalej EG), Rzym 2013, nr 1; Radujcie się, s. 7.

3 Por. A. Spadaro. Svegliate il mondo, (Rozmowa papieża Franciszka z przełożonymi generalnymi), „La civiltà cattolica” 165(2014) 1, s. 5; Radujcie się, s. 8.

${ }^{4}$ Por. Radujcie się, s. 8-9. 
rodu Wybranego. Zaznacza, że w Starym Testamencie radość jest związana z poczuciem bliskości Boga. Warto podkreślić, że w samych Psalmach wyrażenia ukazujące radość jako owoc obecności Boga pojawiają się aż około 100 razy. Wydarzeniom opisanym w Starym Testamencie towarzyszy dwojakiego rodzaju radość. Pierwsza dotyczy wydarzeń codziennych, druga to radość wypływająca z zawartego z Bogiem przymierza. Obok radości powszechnych, dostępnych ogółowi, takich jak: zwycięstwo w bi-

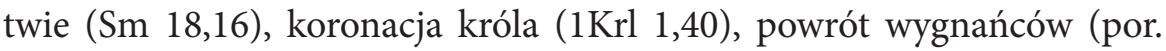
Ps 126,2), istnieje radość bardzo osobista (por. Prz 17,22; 12,25; 15,30) - radość ludzkiego serca. Z kolei radość płynąca z przymierza dotyczy wspólnego kultu, osobistej wierności Bogu i nadziei eschatologicznej ${ }^{5}$. Do tej ostatniej najczęściej odnosi się w swoim nauczaniu Papież Franciszek, przywołując słowa proroka Izajasza.

Prorok ten wzywa wielokrotnie do radości, ukierunkowanej na przyszłość (por. 9,2; 35,1; 44,23; 49,13). Jego nauczanie stanowi motyw wiążący rozważań dokumentu „Radujcie się”. W pierwszej jego części po wprowadzeniu Papieża zamieszczono cytat: „Radujcie się wraz z Jerozolimą, weselcie się, co ją miłujecie...” (Iz 66,10-14) ${ }^{6}$. W kolejnej zamieszczono inny tekst proroka: „Pocieszajcie mój lud” (Iz 40,1-2) 7 .

Księgi starotestamentalne, o czym pisze Papież w swojej adhortacji Evangelii gaudium, miały za zadanie ukazać radość zbawienia, która będzie obfitować w czasach mesjańskich. Papież przytacza obok tekstów proroka Izajasza, takich jak: „Pomnożyłeś radość, zwiększyłeś wesele” (Iz 9,2); „Wznoś okrzyki i wołaj z radości” (Iz 12,6); „Zabrzmijcie weselem, niebiosa! Raduj się, ziemio! Góry, wybuchnijcie radosnym okrzykiem! Albowiem Pan pocieszył swój lud, zlitował się nad jego biednymi” (Iz 49,13); również słowa innych proroków: Zachariasza: „Raduj się wielce, Córo Syjonu, wołaj radośnie, Córo Jeruzalem! Oto Król twój idzie do ciebie, sprawiedliwy i zwycięski” (Za 9,9) i Sofoniasza. Ten ostatni przedstawia Boga jako jaśniejące centrum świata i źródło radości: „Pan, twój

5 Por. Radość, w: Słownik Teologii Biblijnej, red. X.L. Dufour, Poznań 1990, s. 845-846; A. Sobczyk, Znaczenie radości w życiu chrześcijanina, „Katecheta” 53(2008) 5, s. $43-44$.

6 Por. Radujcie się, s. 13.

7 Por. tamże, s. 39-40. 
Bóg, jest pośród ciebie, mocarz, który zbawia, uniesie się weselem nad tobą, odnowi [cię] swoją miłością, wzniesie okrzyk radości” (So 3,17) ${ }^{8}$.

Radość w Nowym Testamencie dzieli się na tę ewangeliczną i radość Zmartwychwstania. Pierwsza dotyczy zbawienia zapowiedzianego maluczkim oraz radości jako daru Ducha Świętego. Uobecnia się w radościach dotyczących tajemnicy Wcielenia Syna Bożego oraz tajemnicy Jego ziemskiego życia. Radość Zmartwychwstania dotyczy wszystkich uczniów Chrystusa cieszących się z ukazania się Zbawiciela9.

Teksty nowotestamentalne przedstawiają radość obejmującą zarówno przeszłość, jak i przyszłość. Ewangelista Łukasz opiewa radość już od wydarzeń poprzedzających narodzenie Zbawiciela. Należą do nich zarówno pozdrowienie anioła skierowane do Maryi: „Raduj się!” (Łk 1,28), jak i poruszenie się z radości Jana Chrzciciela w łonie Elżbiety na dźwięk głosu Maryi usłyszanego przez Matkę (por. Łk 1,41). Sama Maryja głosi: „raduje się duch mój w Bogu, moim Zbawcy” (Łk 1,47). Jan Chrzciciel raz jeszcze wyraża swą radość, gdy Jezus rozpoczyna swoją posługę: „Ta zaś moja radość doszła do szczytu" (J 3,29).

Również Jezus ukazuje i mówi o swej radości. Potwierdza to ewangelista w słowach: „rozradował się [...] w Duchu Świętym” (Łk 10,21); a także przytaczając sytuację, gdy Syn Boży zwraca się do słuchaczy, wyjaśniając, że prawdziwa radość to ta, która pochodzi od Niego (J 15,11; $16,24 ; 17,13)$. Jego orędzie jest źródłem radości: „To wam powiedziałem, aby radość moja w was była i aby radość wasza była pełna” (J 15,11). Chrześcijańska radość czerpie ze źródła tryskającego serca Zbawiciela, który zapewnia: „Wy będziecie się smucić, ale smutek wasz przemieni się w radość” (J 16,20). I podkreśla: „Znowu jednak was zobaczę i rozraduje się serce wasze, a radości waszej nikt wam nie zdoła odebrać” (J 16,22). Natomiast Księga Dziejów Apostolskich zwraca uwagę na radość będącą skutkiem spotkania Jezusa przez uczniów. Radość towarzyszy im także po Jego Zmartwychwstaniu. Świadczy o tym fakt, że tam, gdzie przybywali uczniowie, tam panowała „wielka radość” (por. 8,8), a oni, pośród prześladowania, „byli pełni wesela” $(13,52)$. Wynikało to z faktu, że pośród nich

\footnotetext{
${ }^{8}$ Por. EG 4.

9 Por. Katechizm Kościoła Katolickiego, Poznań 1994, nr 644; A. Sobczyk, dz. cyt., s. 44 .
} 
był Jezus. Spotkanie z Mistrzem, doświadczenie jego obecności w sercach apostołów było źródłem ich radości. Udzielała się ona również ludziom, którzy ich spotykali. Dowodem tego są dopiero co ochrzczony dworzanin, który, „jechał z radością” $(8,39)$, a także strażnik więzienia, który „razem z całym domem cieszył się bardzo, że uwierzył Bogu” $(16,34)^{10}$.

Święty Paweł podaje teologiczną interpretację radości. Według niego jest ona owocem Ducha (por. Ga 5,22). Apostoł Narodów widzi $\mathrm{w}$ niej również stały znak Królestwa (por. Rz 14,17). Do źródeł radości zalicza modlitwę, miłość i dziękczynienie (por. 1 Tes 5,16; Flp 3,1; Kol 1,11). Na temat ostatecznej i wiecznej radości wypowiada się św. Jan Ewangelista. Twierdzi on, że będzie ona towarzyszyła tryumfowi Boga i Baranka (Ap 19,7) ${ }^{11}$.

\section{RADOŚĆ ZE SPOTKANIA Z JEZUSEM JAKO OWOC KONSEKRACJI}

Krótką prezentację zagadnienia radości w Biblii Papież kończy pytaniem: „dlaczego i my nie mielibyśmy zanurzyć się w tym strumieniu radości?" 12 . Pytanie to jest uzasadnione, zwłaszcza że charakterystyczną cechą radości jest jej moc rozprzestrzeniania wraz z orędziem Ewangelii ${ }^{13}$.

Ojciec święty wielokrotnie powtarza, że prawdziwa radość rodzi się ze spotkania z Chrystusem i z relacji z innymi ludźmi. Jej źródłem jest świadomość bycia kochanym i potrzebnym, całkowicie akceptowanym, rozumianym. Porównuje to do wydarzenia powołania człowieka do życia w zakonie, do którego Bóg kieruje ten sam komunikat: „Jesteś dla Mnie ważny, kocham cię, liczę na ciebie”. Osoba wybrana, uświadamiając sobie doniosłość i znaczenie wydarzenia, czuje się szczęśliwa z tego powodu, że to właśnie w tym momencie i w taki sposób spojrzał na nią Jezus. Papież nazywa zrozumienie tego zaproszenia sekretem radości osób zakonnych. Przypomina, że o wyborze drogi kapłańskiej i zakonnej nie decyduje w pierwszej kolejności człowiek. To radość ze spotkania z Je-

\footnotetext{
10 Por. EG 5.

11 Por. Radujcie się, s. 14-15.

12 Por. EG 5.

13 Por. Radujcie się, s. 14.
} 
zusem i z Jego zaproszenia prowadzi do otwarcia się człowieka na Boga i na ludzi, co skutkuje wierną i oddaną służbą w Kościele. Taką postawą powinna się cechować osoba służąca Bogu. Papież podkreśla znaczenie radości osób powołanych w kontekście opinii niektórych współczesnych ludzi, którzy uważają pójście za Chrystusem jako zmarnowanie życia. Odpowiedzi na tak niedorzeczne poglądy mają udzielić same osoby konsekrowane, manifestując radość wybrania i dając świadectwo pójścia dalej za Jezusem. Jego bliskość jest źródłem radości i pomocą im we właściwym przeżywaniu konsekracji zakonnej. Papież zachęca do tego, by osoby konsekrowane były radosnymi świadkami Ewangelii, ludźmi autentycznymi i wiarygodnymi ${ }^{14}$.

Powołanie do życia zakonnego jest Bożym zapewnieniem o Jego bliskości i zaproszeniem, by tę wieź z Chrystusem umacniać. Papież widzi w tym źródło radości człowieka. Co prawda Bóg powołuje każdego człowieka do określonego zadania, jednak osoby konsekrowane mają szczególny powód do radości $\mathrm{z}$ racji wybrania do specyficznej służby Bogu i ludziom (por. Mk 10,21) ${ }^{15}$.

Osoba konsekrowana, zdaniem Papieża, odpowiadając na to Boże wybranie, ma nieustannie „wychodzić” z myślenia o sobie, a otwierać się na egzystencję wokół Chrystusa i Jego Ewangelii (por. Ga 2,20). Zachęca przy tym do retrospekcji swej drogi życia i powołania, do ponownego doświadczenia wydarzenia, które zainicjowało wspólną drogę z Chrystusem ${ }^{16}$.

Papież wzywa osoby zakonne do zatrzymania się nad wyborem, potwierdzenia go i wyruszenia w drogę za Chrystusem w życiu. Stwierdza, że być z Chrystusem oznacza dzielenie z Nim życia. Taka analiza początku drogi zakonnej ma doprowadzić do narodzin dla świadomego powołania i w konsekwencji do odnowienia osobistego spotkania z Jezusem. Ułatwia ona szukanie Chrystusa i trwanie w gotowości życia z Nim w codzienności własnej konsekracji ${ }^{17}$.

${ }_{14}$ Por. Franciszek, Wiarygodni i konsekwentni (Spotkanie z seminarzystami, nowicjuszami i nowicjuszkami Rzym 6.07.2013), ORpol 34(2013) 8-9, s. 42.

15 Por. tamże, s. 42-43; Radujcie się, s. 19-20.

${ }^{16}$ Por. Franciszek, Przemówienie do uczestników Zebrania Plenarnego przełożonych Generalnych, (Rzym 8.05.2013), AAS 105(2013), s. 460-463; Radujcie się, s. 20.

17 Por. EG 3; Radujcie się, s. 21-22. 
Kontynuację tej drogi Papież nakreśla w przesłaniu do uczestników kapituły generalnej zakonu św. Augustyna. Nawiązuje w nim do słów Świętego Zakonodawcy i nakazuje spojrzeć zakonnikowi głęboko we własne serce, w celu dostrzeżenia, czy jest gotowe na rzeczy wielkie, czy czasem nie zostało uśpione przez sprawy tego świata ${ }^{18}$.

Takie podejście do powołania zakonnego pozwala na pogłębianie relacji z Jezusem przez niepokój poszukiwania. Osoba konsekrowana uświadamia sobie wówczas wielkość daru, jakim została obdarowana i własne motywacje do udzielenia odpowiedzi Chrystusowi ${ }^{19}$. Kluczem do znalezienia odpowiedzi jest, zdaniem Papieża, wiara. Dał temu wyraz w swej pierwszej encyklice: Lumen fidei. Napisał w niej: „Wiara otwiera nam drogę i towarzyszy nam na przestrzeni dziejów. Dlatego jeśli chcemy zrozumieć, czym jest wiara, powinniśmy opowiedzieć jej historię, drogę ludzi wierzących... Wiara stanowi odpowiedź na Słowo skierowane do osoby, daną pewnemu Ty, które nas woła po imieniu"20. Wiara pozwala, choć po części, odkryć tajemnicę powołania, które Bóg kieruje do każdego człowieka, a zwłaszcza do osoby konsekrowanej.

Papież przypomina zakonnikom o pamięci i świadomości bycia powołanym przez Boga. Twierdzi, że zarówno biskup, jak i zakonnik czy kleryk nie może utracić istotnego odniesienia do początkowego momentu swojej drogi. Celem powołania jest spotkanie i zjednoczenie z Jezusem (por. Mk 3,14). W rzeczywistości to życie w Chrystusie naznacza wszystko, kim jest i co robi osoba zakonna. Według papieża to życie w Chrystusie jest tym, co zapewnia skuteczność apostolską i owocność posługi, według słów Jezusa: „Przeznaczyłem was na to, abyście szli i owoc przynosili, i by owoc wasz był autentyczny” (por. J 15,16). Ojciec święty podaje metody pogłębiania życia w Chrystusie i w konsekwencji owocności apostolatu osób konsekrowanych. Są nimi: kontemplacja Jezusa, adoracja Najświęt-

18 Por. Franciszek, Niespokojne jest serce nasze (Przesłanie do uczestników kapituły generalnej zakonu Św. Augustyna Rzym 28.08.2013), ORpol 34(2013) 10, s. 47-48; Radujcie się, s. 23.

19 Por. Franciszek, Twórcze drogi zakorzenione w Kościele (Homilia z okazji święta św. Ignacego Loyoli. Rzym 31.07.2013), ORpol 34(2013) 10, s. 41; Radujcie się, s. 23-24.

${ }^{20}$ Franciszek, Encyklika Lumen fidei (dalej LF), nr 8; tenże, Być katechetą to powołanie (Przemówienie do Międzynarodowego Kongresu Katechetów, Rzym 27.09.2013), ORpol 34(2013) 11, s. 39-42. 
szego Sakramentu i przyjęcie Go w Eucharystii. Zaleca głębokie zjednoczenie z Chrystusem w modlitwie oraz umiejętność rozpoznawania Jego obecności w chwilach trudnych i przyjmowania Go w osobach najbardziej potrzebujących. Spotkanie z Synem Bożym nie powoduje izolowania się od ludzi, ale motywuje do tego, aby wyjść na spotkanie $\mathrm{z}$ innymi ${ }^{21}$.

Papież Franciszek zachęca, by odczytywać i weryfikować drogę powołania $\mathrm{w}$ świetle pełnego miłości Bożego spojrzenia. Ono zaprasza, ale odpowiedzi człowiek musi udzielić przez wejście $\mathrm{w}$ relację z Jezusem, wkroczenie na drogę ucznia Chrystusa. Franciszek rysuje w tym miejscu podstawy duchowości osób konsekrowanych, która polega na współpracy z Duchem Świętym, by jego mądrością zgłębiać tajemnice Pana i uczyć się patrzeć na świat jego oczyma. Spotkanie z Chrystusem skłania osobę konsekrowaną do wyjścia z siebie. Stawianie w centrum Chrystusa uwalnia $\mathrm{z}$ egoizmu i troski o siebie. Ścisła relacja z Chrystusem pozwala na życie w Jego miłości. Papież nazywa tę via amoris - drogą ku odrodzeniu i przyobleczeniu się w Chrystusa. Mówi o drodze do swoistej chrystoformizacji (por. 2 Kor 5,17). Jej celem jest stan świętości, sposobem zaś osiągnięcia celu - droga ośmiu błogosławieństw ${ }^{22}$.

Ta droga do zjednoczenia i trwania w Chrystusie zaczyna się na modlitwie. Osoba zakonna, chcąc spotkać Jezusa i przylgnąć do Niego całą sobą, musi Go słuchać. Papież widzi w modlitwie także źródło owocności misji. Zachęca, by prace apostolskie zawsze poprzedzać adoracją Najświętszego Sakramentu i kontemplacją oblicza Syna Bożego ${ }^{23}$.

Kontemplacja wydarzeń codzienności umożliwia dostrzeganie znaków czasu. Pozwala również zauważyć i usłyszeć obecność i natchnienia Ducha Świętego. Kontemplacja stwarza przestrzeń dla profetyzmu ${ }^{24}$.

Według Papieża Franciszka życie konsekrowane ma na celu przyjęcie stylu życia Jezusa i przeniknięcie swego życia Jego Duchem. Papież

${ }^{21}$ Por. Franciszek, Idźmy na rozstaje dróg (Msza św. dla biskupów, kapłanów, zakonników, zakonnic i seminarzystów 27 VII 2013), ORpol 34(2013) 10, s. 17-18.

${ }^{22}$ Por. Franciszek, Świętość nie jest przywilejem nielicznych (Anioł Pański we Wszystkich Świętych. Rzym 1.11.2013), ORpol 35(2014) 1, s. 50.

${ }^{23}$ Por. Franciszek, Ewangelizuje się na kolanach (Homilia w czasie mszy św. na spotkaniu z seminarzystami, nowicjuszami i nowicjuszkami w Roku Wiary. Rzym 7.07.2013), ORpol 34(2013) 8-9, s. 46; Radujcie się, s. 32-33.

24 Por. Radujcie się, s. 33-34. 
nawiązuje w tym miejscu do adhortacji Jana Pawła II Vita Consecrata (1996), gdzie życie konsekrowane zostało ujęte jako sposób uczynienia własnym istnienia i działania Jezusa jako Wcielonego Słowa wobec Ojca i wobec braci ${ }^{25}$. W ten sposób dla Ojca świętego życie konsekrowane jest ciągłym powołaniem do pójścia za Chrystusem i przystosowaniem się do trwania w Jego obecności ${ }^{26}$.

Wierność bycia uczniem i bliskość Chrystusa sprawdza się w doświadczeniu braterstwa. Wspólna realizacja powołania i wspólne głoszenie spotkanego Chrystusa w radości osoby konsekrowanej powoduje, że zasiane dzieło miłości dojrzewa, rozwija się i przynosi owoc ${ }^{27}$.

Papież piętnuje złe rozumienie życia zakonnego, pojmowanego jako schronienie i ucieczka przed światem. Stwierdza, że dojrzałe życie osób konsekrowanych prowadzi do zawierzenia siebie i innych Bogu, do wyjścia do ludzi, głoszenia w świecie ewangelii radości, która rodzi się z bezinteresowności spotkania Chrystusa. Dlatego zachęca osoby konsekrowane, by nie bały się manifestować radości z faktu, że zostały powołane. Ona dynamizuje poczynania, daje siłę i stanowi świadectwo ${ }^{28}$.

\section{RADOŚĆ ZE SPOTKANIA Z PANEM DYNAMIZUJE APOSTOLAT}

Według Ojca świętego Franciszka radość nie jest jakimś dodatkiem czy ozdobą w życiu osób konsekrowanych. Jest ona fundamentem ich życia, wynikającym ze spotkania z Chrystusem. Ona dynamizuje ich życie indywidualne i wspólnotowe oraz uskutecznia apostolat. Zakonnicy i zakonnice są powołani do niesienia radości w świecie ${ }^{29}$.

Powołując się na proroka Izajasza $(66,10)$, Papież podkreśla, że osoby konsekrowane powinny promieniować radością. Są w szczególny sposób powołane do niesienia przesłania radości wynikającej z nadziei i wiary w bliskość Boga pełnego miłości i miłosierdzia. Skuteczność tego

25 Por. Jan Paweł II, Vita consecrata, Rzym 1996, nr 22; Franciszek, Idźmy na rozstaje dróg, s. 18; Radujcie się, s. 25-26.

${ }^{26}$ Por. Radujcie się, s. 27.

${ }_{27}$ Por. Franciszek, Wiarygodni i konsekwentni, s. 43; Radujcie się, s. 34-35; Benedykt XVI, Deus Caritas est, Rzym 2005, nr 17.

${ }_{28}$ Por. Franciszek, Wiarygodni i konsekwentni, s. 43; Radujcie się, s. 45-46.

29 Por. Radujcie się, s. 17-18. 
zadania zależy jednak od głębokości doświadczenia radości w życiu samych zakonników i zakonnic. Jeśli oni sami zakosztują wpierw radości płynącej z intymnej relacji z Chrystusem, wówczas ich przesłanie radości będzie bogatsze i bardziej owocne ${ }^{30}$.

Potwierdza to w swej adhortacji, nauczając, że: „Nie można wytrwać $\mathrm{w}$ ewangelizacji pełnej zapału, jeśli nie jest się przekonanym na podstawie doświadczenia, że to nie to samo: poznać Jezusa lub nie znać Go; że to nie jest to samo: podążać z Nim lub kroczyć po omacku; że to nie jest to samo: raczej móc Go słuchać, niż ignorować Jego Słowo; że to nie jest to samo: raczej móc Go kontemplować, adorować, móc spocząć w Nim, niż nie móc tego czynić. Nie jest tym samym usiłowanie budowania świata z Jego Ewangelią, co czynienie tego jedynie w oparciu o własny rozum. Wiemy dobrze, że życie z Jezusem staje się o wiele pełniejsze i że z Nim łatwiej znaleźć sens wszystkiego. I dlatego ewangelizujemy. Prawdziwy misjonarz, który nigdy nie przestaje być uczniem, wie, że Jezus kroczy z nim, rozmawia z nim, oddycha z nim, pracuje z nim. Dostrzega Jezusa żywego towarzyszącego mu pośród całego zaangażowania misyjnego. Jeśli ktoś tego nie odkryje w samym sercu działalności misyjnej, szybko traci entuzjazm i przestaje być pewnym co do tego, co przekazuje, brakuje mu siły i pasji. A osoba, która nie jest przekonana, która nie jest entuzjastą, która nie jest pewna tego i zakochana w tym co głosi, nie przekonuje nikogo" 31 .

Papież mocno zaznacza, że spotkanie z Jezusem - z miłością Bożą, jest jedynym sposobem na skuteczną ewangelizację. Spotkanie to rodzi przyjaźń, uwalnia od wyizolowanego sumienia i egoizmu, rodzi humanizm i altruizm. Człowiek pozwala się Bogu poprowadzić. Z tego źródła wypływa autentyczna radość ewangelizowania ${ }^{32}$.

Spotkanie z Mistrzem wzmacnia chęć dzielenia się tym dobrem, którego się samemu doświadcza. Papież zauważa, że każde autentyczne doświadczenie prawdy i piękna szuka swej ekspansji, a każda osoba przeżywająca wyzwolenie zyskuje większą wrażliwość wobec potrzeb innych ludzi ${ }^{33}$.

\footnotetext{
${ }^{30}$ Por. Franciszek, Ewangelizuje się na kolanach, s. 45-46; Radujcie się, s. 18-19.

${ }^{31}$ EG 266.

32 Por. EG 8.

${ }^{33}$ Por. EG 9.
} 
Tym powinny cechować się szczególnie osoby Bogu poświęcone i przez niego powołane do życia konsekrowanego. Ten, kto spotkał Chrystusa, jak Samarytanka przy studni, nie może zachować dla siebie tego doświadczenia, ale odczuwa pragnienie, by się nim dzielić, aby prowadzić innych do Jezusa (por. J 4). Osoby konsekrowane w Kościele są posłane, aby wszędzie rozbudzać nadzieję. Duch Święty przynagla je do wychodzenia $\mathrm{z}$ murów klasztornych i prowadzi aż na peryferie ludzkości ${ }^{34}$

Ze spotkania z Chrystusem rodzi się posłannictwo przepełnione radością głoszenia. Spotkanie z Miłością Bożą przemienia osobę konsekrowaną. Według Papieża osoba powołana jest wezwana do tego, by być blisko Chrystusa. Życie osób konsekrowanych polega na relacji napełnionej miłością. Na introspektywnej i retrospektywnej analizie własnego życia i powołania. Natomiast świadomością miłości relacyjnej jest wierność. Nierzadko wymaga ona wytrwałości w niesieniu krzyża. Papież zaznacza, że osoba zakonna jest zjednoczona z Chrystusem wówczas, kiedy nie unika krzyża ${ }^{35}$.

Treścią radości ma być przeżywanie tajemnicy paschalnej Jezusa Chrystusa, przyjęcie Ducha Świętego i ewangelizacja. Ojciec święty Franciszek nazywa te wydarzenia etapami wierności radosnej, kenotycznej, doświadczanej przez całe życie osoby konsekrowanej ${ }^{36}$.

Dostrzega, że współczesny człowiek ma potrzebę doświadczania nadziei i miłości Boga, która daje radość niesienia Bożego pocieszenia innym. W taki sposób orędzie radości się rozprzestrzenia. Powstaje swoisty apostolat radości dla ludzi smutnych i zrozpaczonych. To właśnie zadanie powierza się osobom konsekrowanym. Mają iść i misjonować, głosząc radość, nadzieję i miłość ${ }^{37}$.

Misja ta jest naturalną konsekwencją spotkania z Chrystusem i powołania przez niego osób konsekrowanych do służby Kościołowi. To szczególne zadanie polega na niesieniu ludziom pocieszenia i orędzia

${ }^{34}$ Por. Franciszek, Potrzebny jest tlen Ewangelii (Audiencja dla uczestników zgromadzenia plenarnego Papieskiej Rady ds. Krzewienia Nowej Ewangelizacji 14 X 2013), ORpol 34(2013) 12, s. 18-19.

${ }_{35}$ Por. Radujcie się, s. 30-31; Franciszek, Homilia w czasie mszy św. z kardynałami 14.03.2013, AAS 105(2013), s. 365-366.

${ }^{36}$ Por. Franciszek, Ewangelizuje się na kolanach, s. 46.

37 Por. tamże, s. 46; Radujcie się, s. 40-41. 
Bożej miłości i miłosierdziu. Pocieszenie jest darem Ducha Świętego. Stanowi o Jego obecności w duszy ludzkiej (por. J 14,16-17). Osoby konsekrowane, które powinny odznaczać się głębokim życiem duchowym, są powołane, by - szczególnie w dzisiejszych czasach - nieść zaufanie, nadzieję i radość, zachęcając do spotkania z Chrystusem. Bliskość Zbawiciela daje siłę do niesienia radości w codzienność. Papież nazywa to: „uściskiem Boga”. Od osób konsekrowanych oczekuje, że będą znakiem pełnego człowieczeństwa. Mają być tymi, którzy ułatwiają dostęp do Bożej łaski, pochylając się i wychodząc naprzeciw współczesnemu człowiekowi $\mathrm{w}$ geście pocieszenia ${ }^{38}$.

Papież zachęca osoby konsekrowane do humanizowania wspólnot, w których żyją. Nawiązując do Jana Pawła II, kreśli swoisty rys duchowości komunii, w której osoby konsekrowane powinny wzrastać i którą powinny tworzyć i umacniać tam, gdzie żyją. Zwracając się do sióstr klarysek, Papież podpowiada osobom konsekrowanym, że mają: „pielęgnować przyjaźń między wami, życie rodzinne, miłość pomiędzy wami. I aby klasztor nie był czyśćcem, aby był rodziną. Problemy są, będą, ale, jak się to czyni w rodzinie, z miłością, szukać rozwiązania z miłością; nie niszczyć jej, by je rozwiązać; nie rywalizować. Troszczyć się o życie wspólnotowe, bo gdy w życiu wspólnoty jest tak, jak w rodzinie, to właśnie Duch Święty jest w tej wspólnocie. Te dwie rzeczy chciałem wam powiedzieć: kontemplacja zawsze, zawsze z Jezusem: Jezus, Bóg i Człowiek. I życie wspólnotowe, zawsze z sercem wielkim. Odpuszczając, nie wynosić się, znosić wszystko, uśmiechać się z serca. Znakiem jest radość. I ja proszę dla was o tę radość, która rodzi się właśnie z prawdziwej kontemplacji i daje piękne życie wspólnotowe"39.

Uczucie radości umacnia zakonnika w doświadczeniu braterstwa. We wspólnocie każdy jest odpowiedzialny za wierność Ewangelii i duchowy rozwój współbraci. Eucharystia i codzienne spotykanie Chrystusa jednoczy ludzi, obdarza miłością i radością świadectwa. Papież, mówiąc o rodzinie między niebem a ziemią, o obcowaniu świętych, zwraca uwagę

${ }^{38}$ Por. EG 47; Franciszek, Wiarygodni i konsekwentni, s. 44-45; Radujcie sie, s. $41-42$.

${ }^{39}$ Por. Franciszek, Droga człowieczeństwa Jezusa Chrystusa (Przemówienie do sióstr klarysek w bazylice św. Klary, Asyż 4.10.2013), ORpol 34(2013) 11, s. 16. 
na potrzebę jedności we wspólnocie Kościoła. Podkreśla, że: „Kościół w swojej najgłębszej prawdzie jest komunią z Bogiem, zażyłością z Bogiem, wspólnotą miłości z Chrystusem i z Ojcem w Duchu Świętym, której przedłużeniem jest wspólnota braterska. Ta relacja między Jezusem i Ojcem jest "wzorcem « więzi między nami, chrześcijanami”. Zachęca osoby konsekrowane do umacniania braterstwa. Kluczem do tego dzieła jest, według niego, bliskość eucharystyczna ${ }^{40}$.

Zwracając się do osób konsekrowanych, Papież Franciszek przypomina, że są powołane do przekraczania siebie na drodze adoracji i służby. Mają dawać świadectwo wzajemnego poszukiwania i towarzyszenia jako sprzeciwu wobec kultury wykluczenia i indywidualizmu. Zakonnicy i zakonnice mają uczyć komunii i kultury spotkania z Chrystusem i między ludźmi ${ }^{41}$.

Mają wypełniać to zadanie razem, współpracując, wzajemnie sobie pomagając, uznając własne błędy i prosząc o wybaczenie. Papież podaje kolejne kroki ewangelizacji świata przez osoby konsekrowane. Wymienia: słuchanie, wędrowanie, a następnie misyjność, rozumianą jako głoszenie aż po peryferie ${ }^{42}$.

Według Ojca świętego, to ze świadectwa radości z powołania osób poświęconych Bogu rodzi się siła przyciągania do Kościoła. Papież zachęca do tego, by nie tylko nie wstydzić się takiego sposobu życia, ale by być jego świadkami i obudzić świat poprzez świadectwo spotkania Chrystusa w życiu. Właśnie w taki sposób, przez bliskość i spotkanie, Bóg objawił się ludziom w Tajemnicy Wcielenia. Dlatego osoby konsekrowane mają budzić świat, wzywając do spotkania z Chrystusem w bliskości rodziny Kościoła. Ewangelicznym przykładem jest spotkanie Jezusa z uczniami w drodze do Emaus (por. Łk 24,13-35). Papież nakreśla adresatów posługi osób konsekrowanych. Są nimi: ludzie zmęczeni, słabi, ci, którzy utracili

${ }^{40}$ Franciszek, Wielka rodzina między ziemia i niebem (Audiencja generalna. Rzym 30.10.2013), ORpol 34(2013) 12, s. 38-39; A. Spadaro, Svegliate il mondo, s. 13; Radujcie się, s. 44.

${ }^{41}$ Por. Franciszek, Przemówienie do uczestniczek zebrania plenarnego UISG (Rzym 8.05.2013), AAS 105(2013), s. 460-463; tenże, Idźmy na rozstaje dróg, s. 18.

1. ${ }^{42}$ Por. Franciszek, Kościót wzrasta dzięki atrakcyjności świadectwa (Przemówienie do księży, zakonników i zakonnic w katedrze św. Rufina 4.10.2013), ORpol 34(2013) 11 , s. $13-15$. 
światło i sens dalszej drogi. Im należy przywrócić światło wiary i radość płynącą z nadziei spotkania ${ }^{43}$.

Sprawdzianem autentyczności spotkania osoby konsekrowanej z Chrystusem jest, zdaniem Papieża, dojrzała postawa prowadząca do duszpasterskiego ojcostwa i macierzyństwa. Radość jest znakiem dojrzale przeżywanej konsekracji, która prowadzi do płodności i owocności apostolatu ${ }^{44}$.

Zauważając kryzys ekonomiczny i moralny społeczeństwa zachodniego, Ojciec święty Franciszek podkreśla, że nie jest on przejściowy, ale stanowi istotny moment historyczny. Z tego względu zachęca zakonników, by wyszli ku peryferiom egzystencjalnym, geograficznym i moralnym, by szukać człowieka i nieść radość ze spotkania z Chrystusem ${ }^{45}$.

Osoby konsekrowane powinny żyć nowością, którą sprawia w nich moc Ducha Świętego. Powinny odnajdywać nowość Ewangelii; nieść wiarę i promować dialog. Dzięki temu wzrasta integralna humanizacja, kultura spotkania i relacji. Tak uobecnia się chrześcijański sposób życia i radości z powołania do życia konsekrowanego ${ }^{46}$.

Podsumowując, można zauważyć szczerą troskę Papieża o rozwój duchowy i owocność apostolską osób konsekrowanych. Ojciec święty zachęca zakonników i zakonnice do głębokiej zażyłości z Chrystusem. Ona stanowi źródło radości i gorliwości duszpasterskiej. Radość ta, z kolei, jest owocem konsekracji rozumianej jako pozytywna odpowiedź na powołanie do poświęcenia się na wyłączną służbę Bogu i ludziom. Wymownym obrazem zainteresowania Papieża Franciszka życiem konsekrowanym są jego słowa zawarte w adhortacji Evangelii gaudium, które, co prawda, stanowią zachętę dla wszystkich chrześcijan, ale w kontekście

${ }^{43}$ Por. Franciszek, Duszpasterstwo to realizowanie macierzyństwa Kościoła (Spotkanie z episkopatem Brazylii. Rio de Janeiro 27.07.2013), ORpol 34(2013) 10, s. 21-22; Radujcie sie, s. 46-47.

${ }^{44}$ Por. Franciszek, Wiarygodni i konsekwentni, s. 43-44; Radujcie się, s. 47.

${ }^{45}$ Por. Franciszek, Czuwanie przed Zesłaniem Ducha Świętego z członkami ruchów, nowych wspólnot i stowarzyszeń kościelnych (Rzym 18.05.2013), AAS 105(2013,) s. 450-452; tenże, Niespokojne jest serce nasze, s. 48; Radujcie się, s. 48.

${ }^{46}$ Por. Franciszek, Apokalipsa, która nie nastąpi (Przemówienie do świata akademickiego i kultury. Cagliari 22.09.2013), ORpol 34(2013) 11, s. 27-29; Radujcie się, s. $50-51$. 
roku życia konsekrowanego stanowią szczególnie wyzwanie dla osób zakonnych. Papież napisał: „Zapraszam każdego chrześcijanina, niezależnie od miejsca i sytuacji, w jakiej się znajduje, by odnowił dzisiaj swoje osobiste spotkanie z Jezusem Chrystusem, albo przynajmniej podjął decyzję gotowości spotkania się z Nim, szukania Go nieustannie każdego dnia. Nie ma racji, dla której ktoś mógłby uważać, że to zaproszenie nie jest skierowane do niego. Kto zaryzykuje, by uczynić mały krok w kierunku Jezusa, tego Pan nie zawiedzie, przekona się, że On już na niego czekał z otwartymi ramionami. Nic nie może być większe od Jego życia, które pozwala nam iść naprzód"47.

Streszczenie. Rozpoczął się w Kościele Rok życia konsekrowanego. To doskonała okazja, by przybliżyć charakterystyczne elementy tego specyficznego stylu życia wybieranego przez kobiety i mężczyzn w Kościele od samych jego początków. Warto przeanalizować nauczanie papieskie na temat życia zakonnego, szukając aspektów szczególnie podkreślanych przez papieża Franciszka. Uważna lektura pozwala na wyciągnięcie wniosku, że należy do nich wydarzenie spotkania Chrystusa, które stanowi podstawę duchowości osób konsekrowanych. Spotkanie to jest źródłem autentycznej radości osób Bogu poświęconych. Ono również dynamizuje apostolat i stanowi wyraz świadectwa. $\mathrm{Z}$ tego powodu papież $\mathrm{w}$ swoich dokumentach i wypowiedziach mocno akcentuje potrzebę radosnego głoszenia ewangelii współczesnemu człowiekowi, przez ludzi, którzy doświadczyli spotkania z Jezusem i których serce przeniknęła radość Jego obecności.

Słowa klucze: Papież Franciszek; osoby konsekrowane; radość; duchowość.

Summary. The encounter with Christ as a basis for spirituality of consecrated persons according to the Pope Francis' teaching. In 2015 the Catholic Church celebrates a Year of Consecrated Life. This is an excellent opportunity to speak about the constitutive elements of this specific lifestyle undertaken by women and men in the Church from her very beginning. It is worthwhile analysing papal teaching about the monastic life, looking for its some aspects emphasized by Pope Francis. A careful reading allows to point out that the encounter with Christ Himself is a constitutive basis of spirituality for consecrated persons. This meeting is the source of their authentic joy. It also dynamizes their apostolate and is an expression of their witness. For this reason the Pope in his documents and statements strongly emphasizes the need to proclaim today the gospel with joy. This is a task addressed to people who have experienced the encounter with Jesus and whose hearts have been permeated through by the joy of His presence.

Keywords: Pope Francis; consecrated persons; joy; spirituality.

${ }^{47}$ EG 3. 
